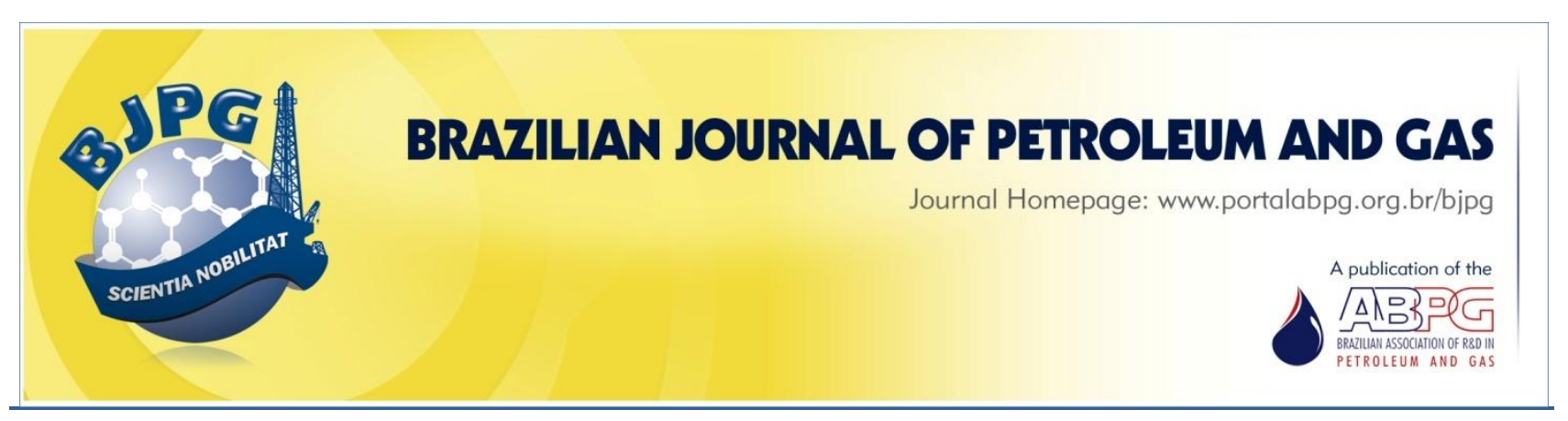

\title{
STUDYING THE INFLUENCE OF ANTIFOAMING ADDITIVES ON CRUDE OIL/AIR INTERFACE: PROPOSAL OF A NEW METHODOLOGY
}

\footnotetext{
${ }^{a}$ Mendes, M. T.; ${ }^{b}$ Ramalho, J. B. V. S.; ${ }^{b}$ Karnitz Júnior, O.; ${ }^{c}$ Palermo, L. C. M.; ${ }^{a, c}$ Mansur, C. R. E. ${ }^{1}$

${ }^{\mathrm{a}}$ Federal University of Rio de Janeiro, Metallurgical and Materials Engineering Program /COPPE, Rio de janeiro - RJ - Brazil

${ }^{\mathrm{b}}$ Leopoldo Américo Miguez de Mello Research and Development Center (CENPES), Petrobras, Rio de Janeiro - RJ - Brazil

${ }^{\mathrm{C}}$ Federal University of Rio de Janeiro, Professora Eloisa Mano Macromolecules Institute, Rio de Janeiro- RJ - Brazil
}

Received: 18.03.2019 / Revised: 17.08.2019 / Accepted: 26.08.2019 / Published on line: 08.10.2019

\begin{abstract}
Foams generated during oil production are complex systems. The complexity of their continuous phase makes it difficult to understand what occurs in the foam layers. Some studies have shown that the main species that stabilize foams are asphaltenes, because they reduce the surface tension of the bubbles with their interfacial activity, causing this surface to become viscoelastic. To understand surface viscoelasticity, it is necessary to investigate the rheology of the crude oil/air interface. Since the great majority of works published have used a Du Noüy ring or BiCone accessory to evaluate the surface only of model asphaltene systems, the aim of this work is to study the crude oil/air interface of different crude oil samples and different antifoaming products using the BiCone accessory.
\end{abstract}

\section{KEYWORDS}

foams; interfacial rheology; crude oil; BiCone accessory

\footnotetext{
${ }^{1}$ To whom all correspondence should be addressed.

Address: Federal University of Rio de Janeiro, Professora Eloisa Mano Macromolecules Institute, Macromolecules and Colloids in the Petroleum Industry Laboratory. Cidade Universitária - Av. Horácio Macedo, 2.030. Centro de Tecnologia - Prédio do Bloco J, Rio de Janeiro - RJ - Brazil.

ZIP Code: 21941-598 | e-mail: celias@ima.ufrj.br

doi:10.5419/bjpg2019-0014
} 


\section{INTRODUCTION}

Each crude oil reservoir has unique conditions of temperature and pressure, where the crude oil has different amounts of dissolved gas in its constitution. During production, as the fluid rises in the pipes, pressure and temperature decrease, causing the previously dissolved gas to be liberated. This activity, along with the agitation that occurs during the extraction process, leads to the formation of foams (Wylde, 2016).

Since non-aqueous foams are less common than aqueous ones, literature review about the former type are scarce, a situation that is aggravated by the complexity of the continuous phase, i.e., the oil, in relation to non-aqueous foams (Blázquez et al., 2016).

With respect to the composition of crude oil, some studies have shown that asphaltenes are adsorbed at the oil-water interface, stabilizing water-in-oil emulsions (Mohammed et al, 1993; Førdedal et al., 1996), and others have indicated that asphaltenes are responsible for stabilizing foam in crude oil (Zaki et al., 2002; Adil \& Maini, 2007; Poindexter et al., 2002). Asphaltenes are defined as the oil fraction that is insoluble in $n$ alkanes and soluble in aromatic solvents (Lobato et al., 2014). Besides this, asphaltenes are the components of oil with the greatest polarity and molar mass (Honse et al., 2012; Khoshandam \& Alamdari, 2010). Due to their interfacial activity, they can organize at the interface, reducing the interfacial tension in the medium where they are introduced (Lobato et al., 2009; Fan et al., 2010; Álvarez et al., 2010).

Viscosity also plays an important role in foam formation (aqueous or non-aqueous) because it is related directly to the drainage of the interstitial fluid in foam (Sheng et al., 1999; Sheng et al., 1997; Wang et al., 2009; George et al., 2005). Besides reducing the drainage rate, systems with high viscosity can also diminish the rate of gas diffusion between the bubbles, a phenomenon known as Ostwald ripening, which is the reduction of the polydispersion of gas bubbles, promoting the stability of foam (Koehler, 2012). Poindexter and collaborators (Poindexter et al., 2002) indicated that crude oils with viscosities below $150 \mathrm{CP}$ (37.8 ${ }^{\circ} \mathrm{C}$ ) produce little to no foam. On the other hand, Fraga and collaborators (Fraga et al., 2011) evaluated high-viscosity oil samples and reported that they do not generate foam, even when containing high levels of stabilization species.

Depending on the stress applied and the timing of application, foams can behave as solids or liquids. By increasing the gas-liquid interfacial area and energy per unit of volume, the foam will become elastic due to the stress applied. When the stress applied is greater than what the liquid film can withstand, the bubbles will become rearranged and the foam will flow like a non-Newtonian viscous fluid (Höhler \& Cohen-addad, 2005).

Liquid foams are systems that resemble emulsions, since surfactants are present to stabilize the liquid-gas interface. Like an emulsion, the interfacial layer of the foam becomes viscoelastic due to the presence of amphiphilic species, which have superficial action and can be adsorbed through the dispersed or continuous phase. Therefore, rheological analysis of this interface is necessary to understand its characteristics and stability, since the lifetime of this foam is closely associated with these conditions (Langevin, 2000).

Interfacial rheology permits studying the interface flow properties of systems controlled by the presence of surfactants adsorbed at the interface (Krägel \& Derkatch, 2010). Rheological investigations are very important to supply information about the behavior of emulsions, such as the kinetics of film formation, adsorption of surfactants, and rupture of the interfacial film (Tadros, 2004; Spiecker \& Kilpatrick, 2004; Ekott \& Akpabio, 2010; Phukan et al., 2010).

Interfacial rheology also provides information on the functional interplay of the deformation of an interface, the forces acting on it, and the resulting flows in the adjacent phases of the fluid. This can be accomplished by applying dilatation and shear methods (Krägel \& Derkatch, 2010).

Presently, basically two methods are used to measure the rheology of interfacial films using the shear method: one with the Du Noüy ring and the other with the BiCone accessory. The BiCone accessory is more robust than the ring, facilitating its positioning on the surface of the liquid with much greater precision. This makes the analyses more reproducible than when using the Du Noüy ring (Heyer \& Läuger, 2008). 
Some studies have evaluated the asphaltene/air and asphaltene/water interfaces of solutions using the Du Noüy ring (Oliveira et al., 2017), while others have used the BiCone accessory (Fan et al., 2010; Spiecker \& Kilpatrick, 2004; Kilpatrick \& Spiecker, 2001). However, to the best of our knowledge, no studies have been published involving rheological analysis applied at the crude oil/air interface to investigate the formation of foams.

Therefore, the aim of this study is to develop a method involving interfacial rheology applied to the crude crude oil/air interface focusing on the formation of foams with or without the presence of antifoaming additives.

\section{EXPERIMENTAL PART}

\subsection{Materials}

Foam formation tests in crude oil and the rheology of the crude oil/air interface were performed with and without the presence of antifoaming additives. Two commercial siliconebased antifoaming agents were used, here called AF1 (with high silicone content) and AF2 (with low silicone content), both donated by the Petrobras Research Center (CENPES, Rio de Janeiro, Brazil).

Tests were also conducted with a formulation composed of a nonionic surfactant based on poly(ethylene oxide)-poly(propylene oxide) block copolymer (Pluronic 31R1), supplied by Sigma Aldrich (São Paulo, Brazil). This formulation was prepared using solvents Solbrax 175-235 (S), donated by CENPES, and butanol (B), purchased from Vetec (Rio de Janeiro, Brazil). The surfactant Pluronic 31R1 was dissolved in this solvent mixture in the $S: B$ ratio of $50: 50 \mathrm{v} / \mathrm{v}$, and the product:mixture ratio was $50: 50 \mathrm{v} / \mathrm{v}$. This formulation is identified as FP31R1.

Foam formation tests in oil and of crude oil/air interfacial rheology were conducted using two samples of crude oil from Brazilian wells, donated by CENPES. These were characterized regarding ${ }^{\circ} \mathrm{API}$ density and viscosity, and were identified as crude oils P1 and P2.

The solvents used were $\mathrm{n}$-heptane and toluene, purchased from Vetec (Rio de Janeiro, Brazil).

\subsection{Methods}

\subsubsection{Characterization of the crude oil samples}

Crude oil samples were characterized for obtaining their densities and viscosities.

The density of crude oil is expressed, based on specific conditions, as the API gravity, which is a dimensionless metric (Szklo, 2005). It was created by the American Crude Oil Institute, and can be obtained by Equation (1):

${ }^{\circ} A P I=\frac{141.5}{\rho_{16.5^{\circ} \mathrm{C}}}-131.5$

where $\rho_{16.5{ }^{\circ} \mathrm{C}}$ is the density of the oil at temperature of $16.5^{\circ} \mathrm{C}$.

The densities of the crude oil samples were measured with an Anton Paar DMA 4500 M digital density meter.

The absolute viscosity values of the crude oil samples were determined in the shear rate $(\gamma)$ interval from 0 to $400 \mathrm{~s}^{-1}$ with a Haake Mars 60 rotational rheometer, with $\mathrm{C} 60$ geometry and angle of $1^{\circ}$ (cone-plate).

Viscosities of the samples $\mathrm{P} 1$ and $\mathrm{P} 2$ were determined at temperatures of 60 and $30{ }^{\circ} \mathrm{C}$, respectively. Besides these analyses, the viscosities were measured of the samples diluted in mixtures of n-heptane:toluene (Heptol), with P1 containing $33 \%$ Heptol $(7: 3)$ or $24 \%$ Heptol (3:7), and P2 containing $5 \%$ Heptol (7:3) or $5 \%$ Heptol (3:7) were measured. These analyses were performed at 25 ${ }^{\circ} \mathrm{C}$.

\subsubsection{Foam formation test}

The tests of the foam formation in the two crude oil samples were carried out according to the method described by Fraga (Fraga et al., 2011) and Rezende (Rezende et al., 2011). The tests were performed using a Fann High Temperature Aging Cell ${ }^{\circ}$, containing $150 \mathrm{~mL}$ of the pure samples or mixtures with additives. After inserting each sample, the cell was closed and connected to a compressed air line at pressure of 200 psi for 3 minutes. Then, the cell was placed in a Fann 704Es roller oven at rotation of $50 \mathrm{rpm}$, preheated to $60^{\circ} \mathrm{C}$ for crude oil P1 and to $30^{\circ} \mathrm{C}$ for $\mathrm{P} 2$, for a period of 1 hour. 
Following, the compression cell was placed in vertical position and its outlet was connected to a $150 \mathrm{~mL}$ graduated cylinder. Then, the cell's valve was slowly opened to allow the foam to escape, until reaching an initial height of $80 \mathrm{~mL}$. The height of the foam was read at intervals of 15 seconds until reaching a constant height to obtain consecutive values indicating the total breakdown of the foam. The percentage of foam was calculated by Equation (2):

Foam $(\% v / v)=\frac{H-H_{F}}{H_{F}} X 100$

where $\mathrm{H}$ is the initial height reached by the foam and $H_{F}$ is the final height of the liquid after total breakdown of the foam.

All the tests were performed in duplicate and the means of the data were used to plot the graphs.

The tests, in the presence of the antifoaming additives, were carried out at concentrations of 20 ppm of antifoaming agent AF1, 20 ppm of AF2, and $100 \mathrm{ppm}$ of the formulation FP31R1.

\subsubsection{Evaluation of the precipitation of asphaltenes}

Asphaltene precipitation tests were performed to evaluate the percentage of $n$-heptane necessary to start the precipitation of asphaltenes in the crude oil samples $\mathrm{P} 1$ and $\mathrm{P} 2$.

The precipitation onset point refers to the volume of the flocculant (n-heptane) necessary to start the precipitation of the asphaltenes present in $1 \mathrm{~mL}$ of a model solution or crude oil sample. The asphaltene precipitation onset was measured with a near-infrared (NIR) spectrophotometer, at a wavelength of $1600 \mathrm{~nm}$, utilizing an external probe with $5 \mathrm{~mm}$ optical path inserted in a flask containing the crude oil. The flocculant (n-heptane) was added with the help of a chromatographic pump with flow of $2 \mathrm{~mL} / \mathrm{min}$ (Kallevik et al., 2000). In this test, 10 grams of crude oil was used, so the volume of flocculant ( $n$-heptane) relative to the lowest absorbance value was divided by 10 to express the asphaltene precipitation onset point in terms of $\mathrm{mL}$ of flocculant/g of sample.

\subsubsection{Evaluation of the rheological properties of the crude oil/air interfacial films}

The rheological properties of the interfacial films of the crude oil/air systems were determined with a Haake Mars 60 rotational rheometer using the BiCone accessory. This device works by imposing torque on the measurement instrument (BiCone), which responds by applying oscillatory shear forces at the interface of the system being analyzed and collecting data to calculate the properties of the fluid in question.

The measurement cell comes with a glass cuvette insert with a recess mark in the middle for correct filling. The interface layer of the test sample can be observed through openings in the external measuring cup, which is closed with a twopiece lid with a hole in the center for the measuring shaft of the BiCone rotor. For temperature control, the measuring cup can be positioned at the base of the rheometer (Peutier).

The main objective of this study was to observe the influence of the antifoaming formulations on the values $G^{\prime}$ and $G^{\prime \prime}$ (elastic modulus and viscous modulus, respectively) of the interfacial films. These properties are very important to understand the antifoaming action mechanism at the crude oil/air interfacial layer. In all tests, crude oil samples, with or without antifoaming formulations, were left in the accessory for 17 hours (aging time), to assure adsorption of the asphaltenic fractions at the crude oil/air interface.

Initially, oscillatory shear tests were performed with variation of deformation in an interval between 1 and $5000 \%$, at a constant frequency of 1 $\mathrm{Hz}$, with the pure crude oil samples ( $\mathrm{P} 1$ and $\mathrm{P} 2)$, to determine the linear viscoelasticity region. Then, tests were performed at constant frequency and deformation, selected in the linear viscoelastic region of the graphs plotted previously, for a period of 1 hour. These tests were run with crude oil P1, with or without the antifoaming agents, adjusted so that the oil temperature value during the analysis was $60^{\circ} \mathrm{C}$, and with sample $\mathrm{P} 1$ diluted to different concentrations of Heptol, at $25{ }^{\circ} \mathrm{C}$. Tests were also performed with pure crude oil P2, adjusted so that the oil temperature value during the analysis was $30{ }^{\circ} \mathrm{C}$. Before all tests, crude oil samples containing the formulations were homogenized for 3 hours. 


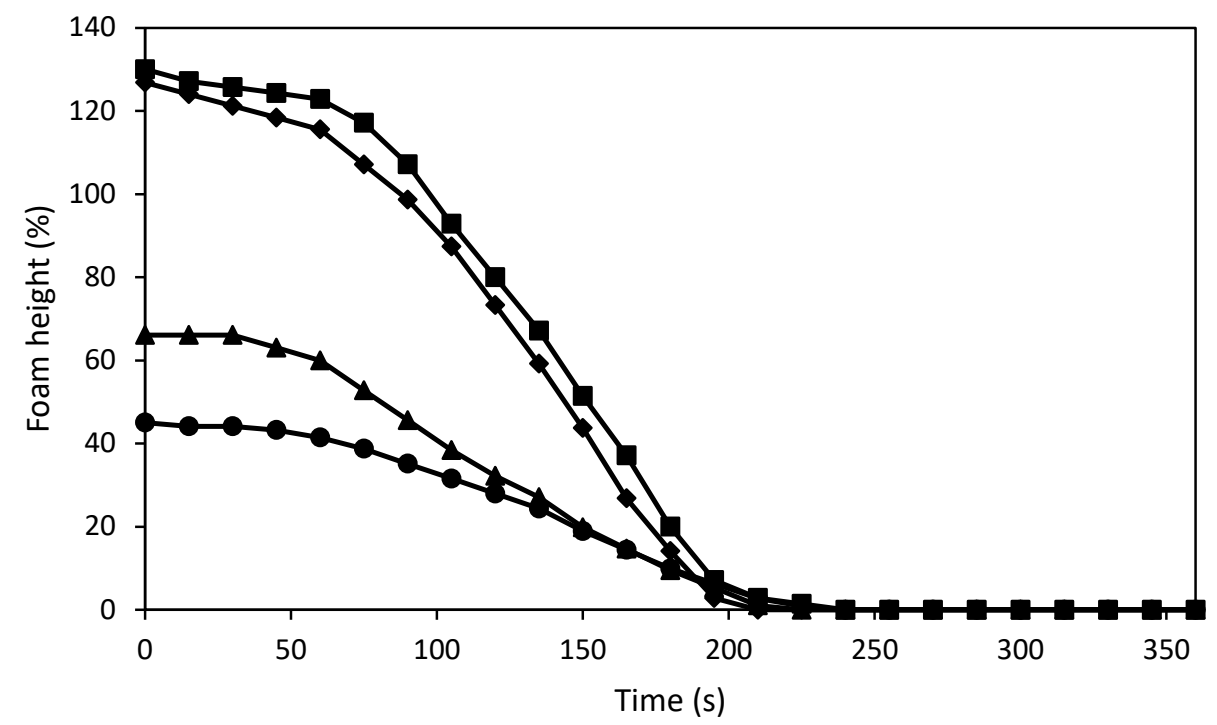

(a)

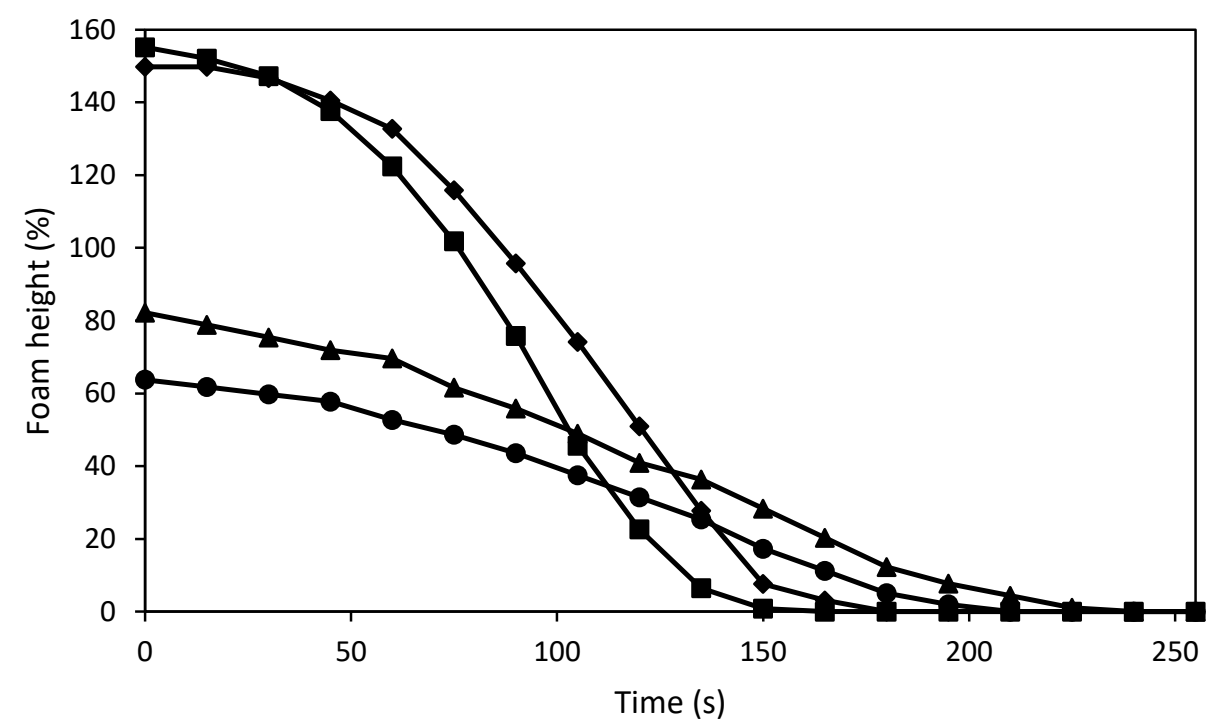

(b)

Figure 1. Efficiency of the antifoaming additives in the crude oil samples: a) P1 (at $60^{\circ} \mathrm{C}$ ) and b) P2 (at $\left.30^{\circ} \mathrm{C}\right):(\mathbf{\square})$ pure crude oil; $(\diamond)$ with FP31R1; $(\mathbf{\Delta})$ with AF2; $(\bullet)$ with AF1.

\section{RESULTS AND DISCUSSION}

\subsection{Characterization of crude oil samples}

Crude oil P1 had a density of $19^{\circ} \mathrm{API}$, classified as heavy crude oil, while P2 had a $26^{\circ}$ API value, being classified as light crude.

Viscosity analyses showed that crude oil P1 had viscosity of $213 \mathrm{cP}$ and $\mathrm{P} 2$ had viscosity of $78 \mathrm{cP}$, both at temperature of $25^{\circ} \mathrm{C}$. In turn, $\mathrm{P} 1$ presented viscosity of $40 \mathrm{cP}$ at $60^{\circ} \mathrm{C}$ and $\mathrm{P} 2$ had viscosity of 70 $\mathrm{cP}$ at $30^{\circ} \mathrm{C}$.

\subsection{Tests of the antifoaming efficiency of the additives}

Tests were performed with pure crude oil samples P1 and P2 and with the presence of the antifoaming formulations investigated in this work: AF1 or AF2, both at concentration of $20 \mathrm{ppm}$, or FP31R1, at concentration of $100 \mathrm{ppm}$. The tests with P1 (Figure 1a) were carried out at a temperature of $60^{\circ} \mathrm{C}$ and those with P2 (Figure $1 \mathrm{~b}$ ) were performed at $30^{\circ} \mathrm{C}$.

The products typically used to minimize the 


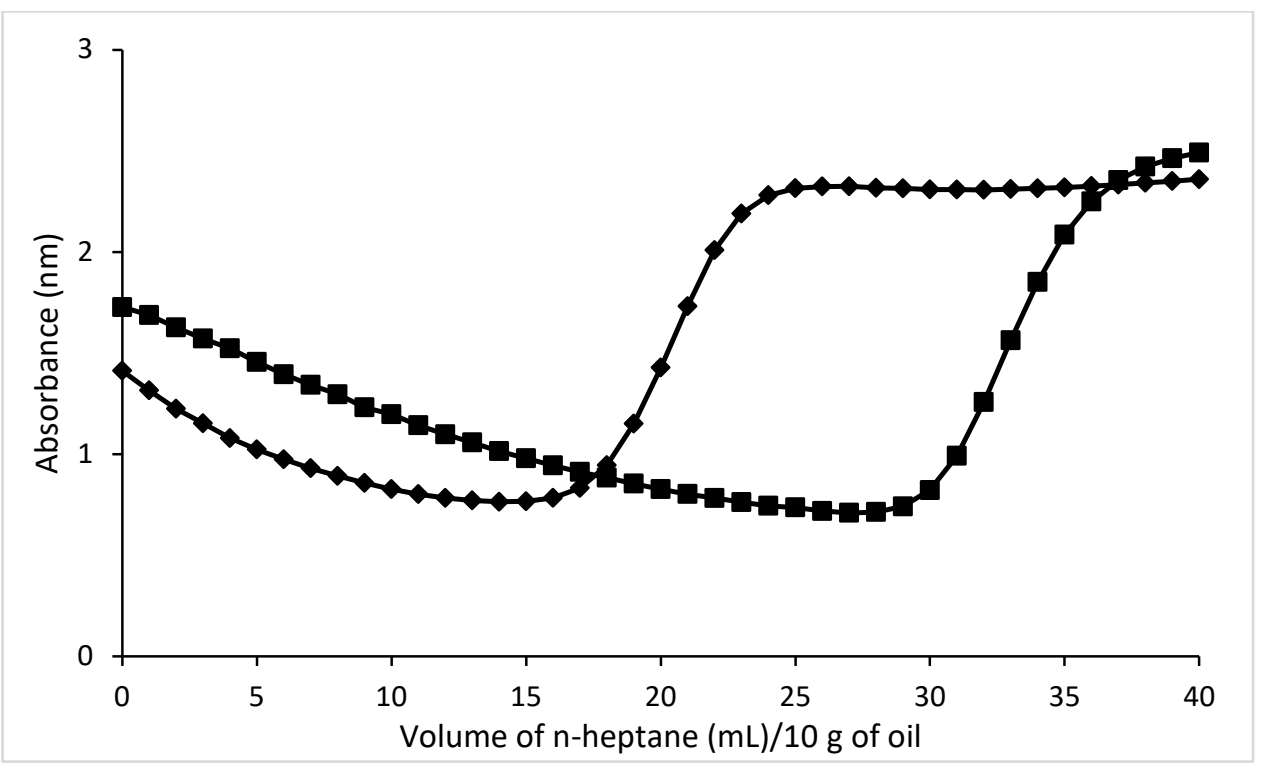

Figure 2. Absorption in the near-infrared range in function of n-heptane concentration, of: (घ) P1; (४) P2.

problem of foaming in separator vessels of production wells contain silicone in their composition, more precisely polydimethylsiloxane (PDMS). These products have the greatest efficiency as antifoaming agents (Fraga et al., 2011; Blázquez et al., 2014; Blázquez et al., 2017; Rocker et al., 2011). Results found in this study corroborate those findings, as can be seen in Figure 1. The efficiency of AF1 is slightly better than the efficiency of AF2, and both have better efficiency than FP31R1.

\subsection{Evaluation of asphaltene precipitation}

The tests to determine asphaltene precipitation onset in crude oils P1 and P2 (Figure 2) were performed by near-infrared (NIR) spectrometry. These tests sought to identify the volume of $n$ heptane for dilution of these samples to be used in interfacial rheology analyses. This volume should be below the asphaltene precipitation point, since, from that point onwards, the asphaltene molecules start to precipitate, impairing the use of that dilution. Here, the $n$-heptane was used in solution with toluene (Heptol) in the study of the influence of dilution of the crude oil samples on interfacial rheology.

The curves in Figure 2 show the NIR absorbance as a function of volume of $n$-heptane added to the pure crude oil. The lowest point on the curve of P1 is at n-heptane volume of $27 \mathrm{~mL}$, while the minimum point on the curve of $\mathrm{P} 2$ is $15 \mathrm{~mL}$. These points indicate asphaltene precipitation onset, i.e., the quantity of flocculant necessary to promote the appearance of the first asphaltene aggregates. These values correspond to onsets of 2.7 and 1.5 $\mathrm{mL}$ of $\mathrm{n}$-heptane/g of oil (after dividing by 10 , since the tests were conducted with $10 \mathrm{~g}$ of crude oil), respectively.

A simple rule-of-three calculation gives the corresponding volume of $n$-heptane at the onset represented on the graph, that is, about $64 \% \mathrm{v} / \mathrm{v}$ for $\mathrm{P} 1$ and $50 \% \mathrm{v} / \mathrm{v}$ for $\mathrm{P} 2$. Therefore, all concentrations of n-heptane, in Heptol, utilized in the tests of viscosity and interfacial rheology were lower than these values.

\subsection{Evaluation of pure and diluted crude oil samples viscosities}

To evaluate the effect of diluting the oil samples on the formation of crude oil/air interfacial film, the n-heptane/toluene (Heptol) mixture was added in proportions of 7:3 and 3:7 for P1 (Figure 3) and P2 (Figure 4), respectively. The purpose was to reduce the viscosity of the samples to reduce the viscous modulus, without causing a significant influence on the aggregation state of the asphaltenes.

Initially, continuous shear tests were performed to obtain flow curves (viscosity as a function of shear rate). 


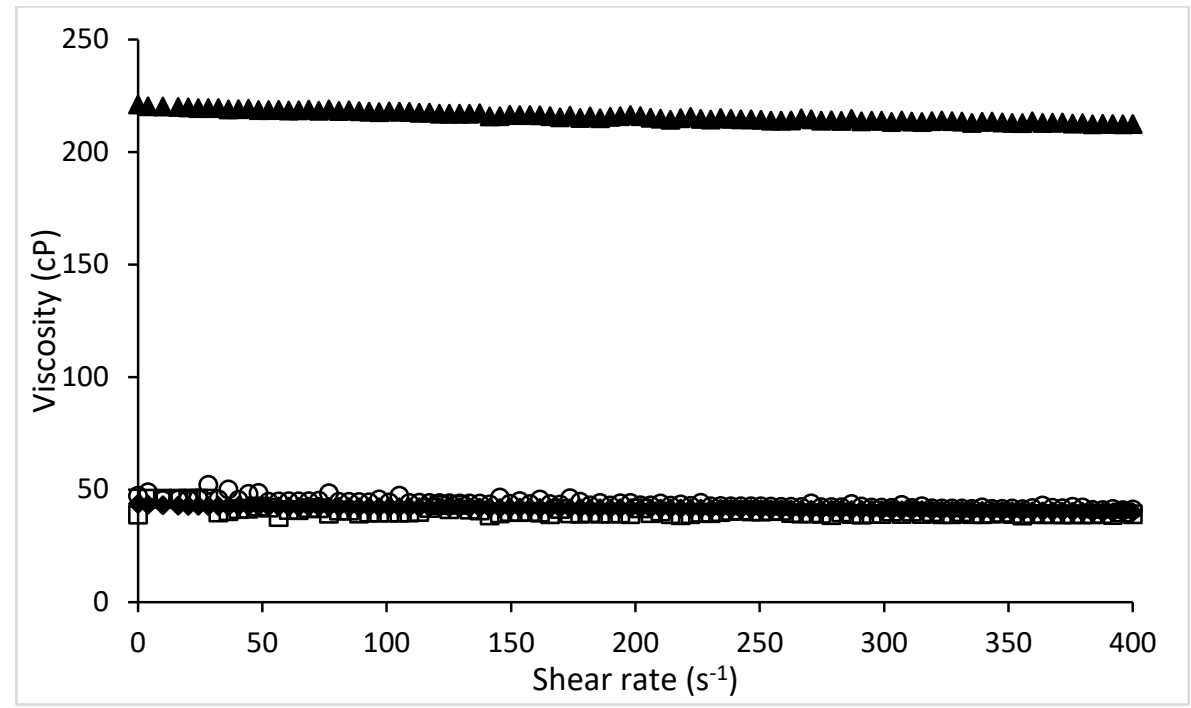

Figure 3. Influence of shear rate on viscosity for: ( $\downarrow) \mathrm{P} 1$ at temperature of $60{ }^{\circ} \mathrm{C}$ and ( $\mathbf{\Delta}$ ) P1; (0) P1 with $33 \%$ Heptol (7:3) and () P1 with 24\% Heptol (3:7), at temperature of $25^{\circ} \mathrm{C}$.

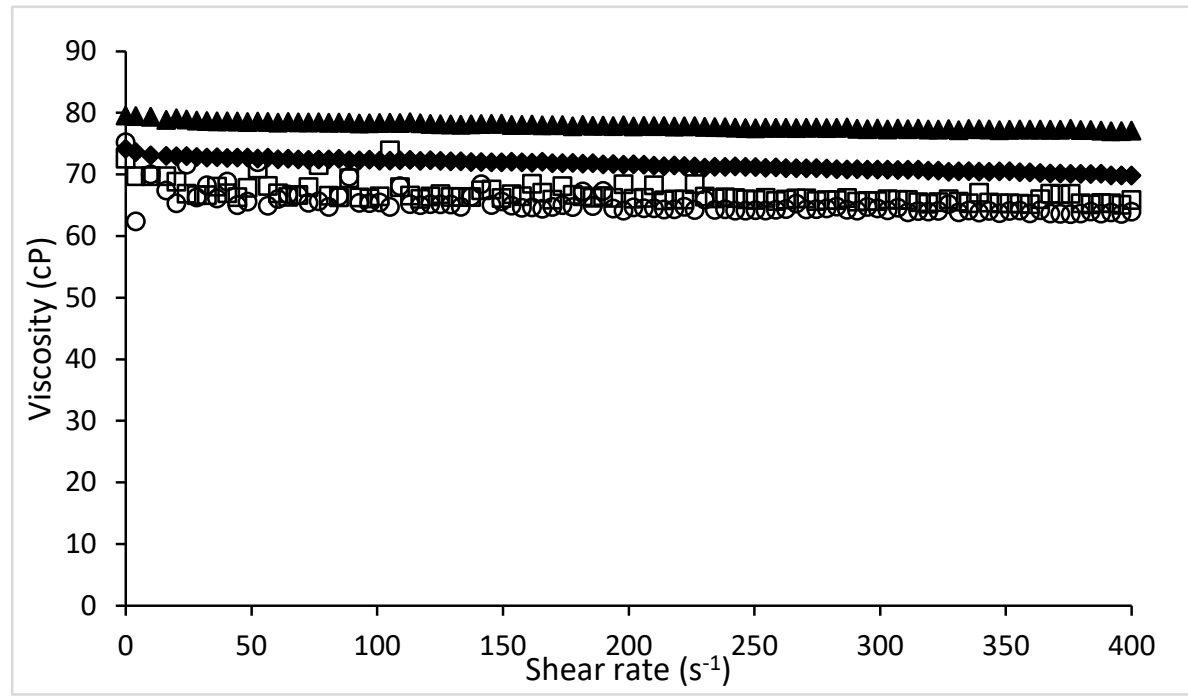

Figure 4. Influence of shear rate on viscosity for: ( $\bullet$ P2 at temperature of $30^{\circ} \mathrm{C}$ and ( $\mathbf{\Delta}$ ) P2; (0) P2 with $5 \%$ Heptol (7:3); () P2 with 5\% Heptol (3:7), at temperature of $25^{\circ} \mathrm{C}$.

These rheological tests were performed to determine the mixture of Heptol. These tests also determined the concentration in the crude oil samples with the same viscosity as the pure samples, when these were analyzed at the temperatures at which the foam efficiency formation tests were carried out. Results indicated the best systems for the interfacial rheology tests at temperature of $25{ }^{\circ} \mathrm{C}$, by reproducing the behavior of the pure crude oil samples at the test temperature of $60{ }^{\circ} \mathrm{C}$.

Results shown in Figures 3 and 4 demonstrate that the variation of shear rate did not cause a significant change in the viscosity of crude oil samples. They also show that the variation of temperature from $25{ }^{\circ} \mathrm{C}$ to $60{ }^{\circ} \mathrm{C}$ caused a significant change in the viscosity of crude oil P1 (at $25^{\circ} \mathrm{C}$, the viscosity was around $213 \mathrm{cP}$ while at 60 ${ }^{\circ} \mathrm{C}$ it was nearly $40 \mathrm{CP}$ ). In turn, at $30{ }^{\circ} \mathrm{C}$ temperature, sample $\mathrm{P} 2$ had approximate viscosity of $70 \mathrm{cP}$.

Under these conditions, it was possible to observe that the systems (at temperature of $25^{\circ} \mathrm{C}$ ) that presented viscosities similar to those of P1 (at 
temperature of $60{ }^{\circ} \mathrm{C}$ ) were composed of crude oil diluted with $33 \%$ (v/v) Heptol 7:3 and 24\% (v/v) Heptol 3:7. With these mixtures, the final concentrations of heptane in the crude oil were about $23 \%$ and $7 \%$, respectively.

In turn, for crude oil P2, even for the lowest concentration of $5 \%(\mathrm{v} / \mathrm{v})$ for both Heptol mixtures (7:3 and 3:7), the sample at this dilution had lower viscosity than the pure crude oil. Since Heptol concentrations lower than $5 \%(\mathrm{v} / \mathrm{v})$ would not have produced a diluted system, no interfacial rheology tests were conducted with diluted crude oil.

The selected crude oil/Heptol systems were, then, submitted to oscillatory tests using the BiCone accessory to evaluate the crude oil/air interface in the presence of the antifoaming products AF1, AF2, and FP31R1, which were also used in the foam formation tests.

\subsection{Evaluation of the rheological properties of the crude oil/air interfacial films}

The stability of foam results from the formation of an elastic interfacial film. Aggregates of the oil phase are adsorbed at the crude oil/air interface, mainly composed of asphaltenes, forming a physical barrier that impedes the collapse of the bubbles forming the foam (Poindexter et al., 2002). Therefore, it is necessary to study the interfacial properties involving the foam breakdown process. Interfacial phenomena such as variation of the viscous modulus $\left(G^{\prime}\right)$ and elastic modulus $\left(G^{\prime \prime}\right)$ determine the stability and other properties of the foam.

The rheological properties of the interfacial films obtained with samples P1 and P2 were evaluated with a Haake Mars 60 rotational rheometer employing the BiCone accessory. Since we did not find any studies of crude oil/air interfacial rheology, it was necessary to develop a testing method.

\section{-Results obtained with crude oil P1 in the presence of the Heptol mixture}

Initially, rheological tests were performed with crude oil P1 (19\% API) containing 33\% Heptol (7:3) and also containing $24 \%$ Heptol (3:7). The tests were conducted with deformation variation of 1 to $5000 \%$ and fixed frequency of $1 \mathrm{~Hz}$ to observe the maximum deformation until rupture of the interfacial film (Figures 5 and 6 ).

The elastic modulus was greater than the viscous one, indicating the formation of an elastic film, which ruptured with deformation of around $900 \%$ in the test conducted with 33\% Heptol 7:3 (Figure 5), and about $268 \%$ in the test with $24 \%$ Heptol 3:7 (Figure 6). These results indicate greater resistance of the interfacial film formed in the presence of a larger quantity of asphaltene flocculant (n-heptane, Figure 5).

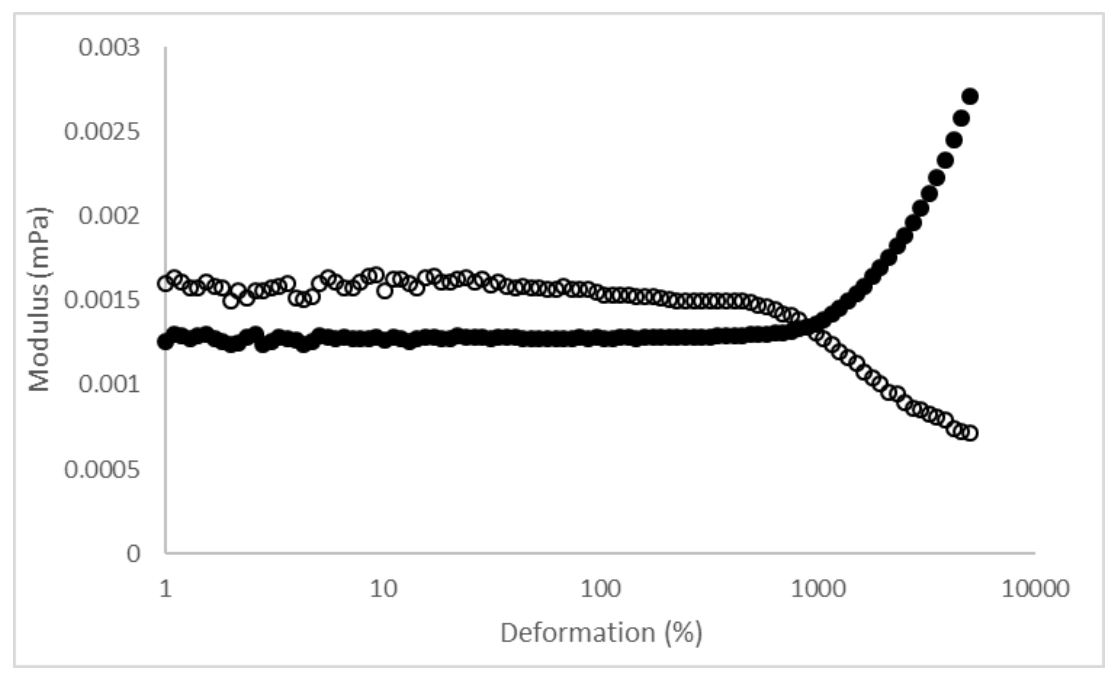

Figure 5. Measures of $\mathrm{G}^{\prime}(\mathrm{O})$ and $\mathrm{G}^{\prime \prime}(\bullet)$ in function of variation of deformation of the interfacial film formed by crude oil P1 (19 $\left.{ }^{\circ} \mathrm{API}\right)+33 \%$ Heptol (7:3), aged for 17 hours, at frequency of $1 \mathrm{~Hz}$ and temperature of $25^{\circ} \mathrm{C}$. 


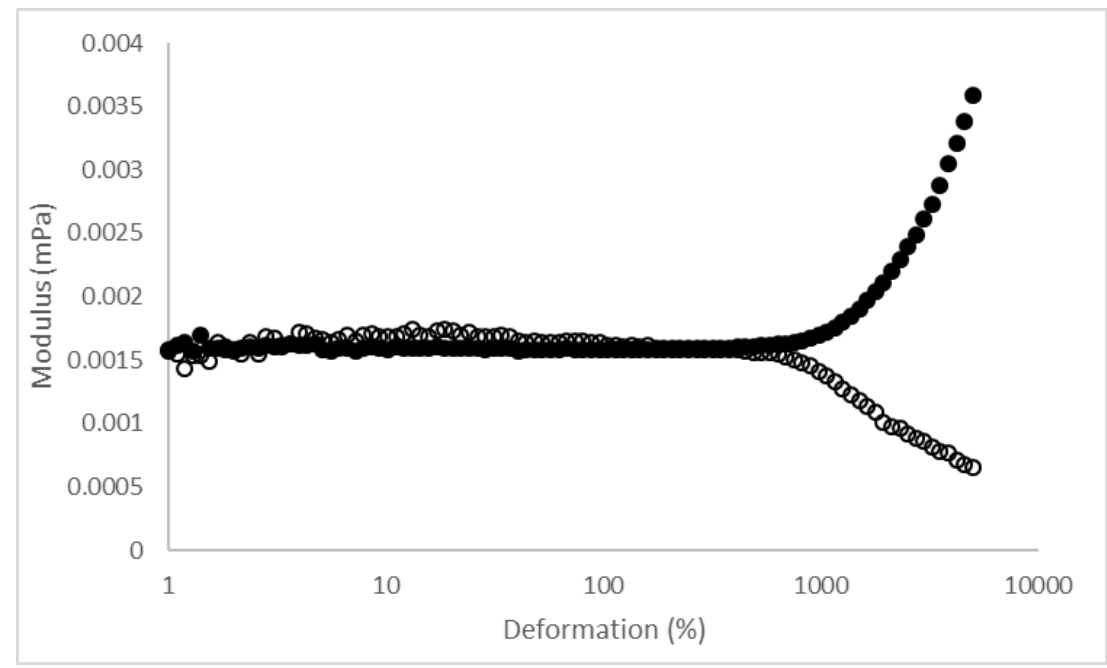

Figure 6. Measures of $\mathrm{G}^{\prime}(\mathrm{O})$ and $\mathrm{G}^{\prime \prime}(\bullet)$ in function of variation of deformation of the interfacial film formed by crude oil P1 (19 $\left.{ }^{\circ} \mathrm{API}\right)+24 \%$ Heptol (3:7), aged for 17 hours, at frequency of $1 \mathrm{~Hz}$ and temperature of $25^{\circ} \mathrm{C}$.

The behavior observed in Figure 5 might be associated with the dilution of the crude oil, favoring the formation of larger quantities (or sizes) of asphaltene agglomerates, due to the greater quantity of flocculant (n-heptane). In this case, it appears that the excess of flocculant favors the formation of a more resistant interfacial film. Nevertheless, a larger quantity of toluene (asphaltene dispersant) apparently diminishes the size of the aggregates and, thus, lowers the resistance of the crude oil/air interfacial film (Figure 6). It is also possible to observe an increase in the viscous modulus in the presence of more toluene, indicating better dispersion of the asphaltenes in the crude oil.

Following, we performed an oscillatory shear test with a variation of time, at a constant shear rate of $10 \%$ and constant frequency of $1 \mathrm{~Hz}$. These conditions were determined based on the inspection of the linear viscoelastic region of the graphs shown in Figures 5 and 6 (where the interfacial film was still intact). In these tests, the behavior was monitored for the elastic modulus $\left(G^{\prime}\right)$ and viscous modulus $\left(G^{\prime \prime}\right)$ as a function of variation of time in the interfacial films formed in:

- Crude oil $1\left(19^{\circ} \mathrm{API}\right)+33 \%(\mathrm{v} / \mathrm{v})$ Heptol 7:3, at temperature of $25^{\circ} \mathrm{C}$ (Figure 7);

- Crude oil $1\left(19^{\circ} \mathrm{API}\right)+24 \%(\mathrm{v} / \mathrm{v})$ Heptol 3:7, at temperature of $25^{\circ} \mathrm{C}$ (Figure 8 ).

These systems were also evaluated in the presence of antifoaming agents AF1 and AF2, both at a concentration of $20 \mathrm{ppm}$, and also in the presence of the formulation FP31R1 at a concentration of $100 \mathrm{ppm}$.

All the graphs present the elastic modulus/viscous modulus as a function of time of analysis, to evaluate the film formed at the crude oil/air interface (Figures 7 and 8).

Figure 7 compares the curves of the elastic modulus/viscous modulus in function of time for the systems formed with crude oil $1\left(19^{\circ} \mathrm{API}\right)$ containing $33 \%(\mathrm{v} / \mathrm{v})$ Heptol $(7: 3)$. As a result, no significant variation occurred between the interfacial film formed at the crude oil/air interface with or without the presence of the additives. But these results were inconclusive because the dilution carried out with the higher amount of the asphaltene flocculant might have favored an increase in resistance of the interfacial film due to the increased size or quantity of asphaltene aggregates.

Figure 8 shows the variation of the elastic modulus/viscous modulus ratio as a function of time for the systems formed by crude oil 1 (19 ${ }^{\circ} \mathrm{API}$ ) containing $24 \%$ Heptol (3:7), with or without the presence of the additives. In these systems, the presence of the antifoaming additives AF1 and AF2 did not cause a significant variation in the interfacial film, but in the presence of FP31R1 (with lower efficiency in breaking down foam), there was a significant increase in the elasticity of the interfacial film. 


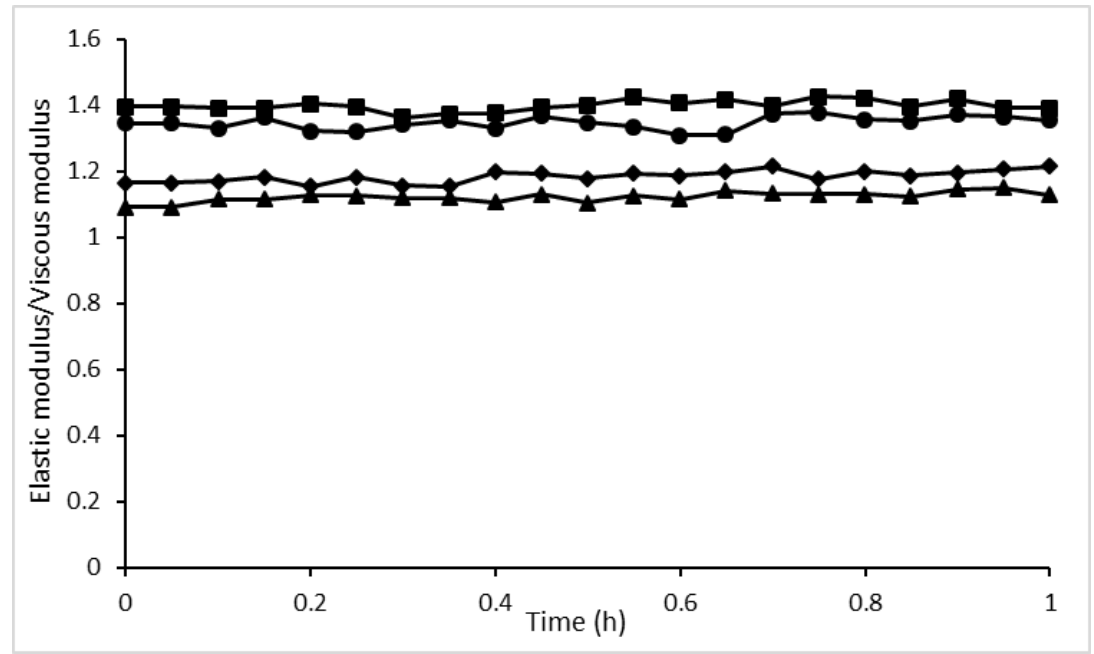

Figure 7. Elastic modulus in function of viscous modulus: (a) crude oil P1 diluted with 33\% (v/v) Heptol (7:3); and this solution containing: $(\bullet)$ FP31R1; $(\Delta) A F 2$; and $(\bullet)$ AF1, at shear rate of $10 \%$, frequency of $1 \mathrm{~Hz}$ and temperature of $25^{\circ} \mathrm{C}$.

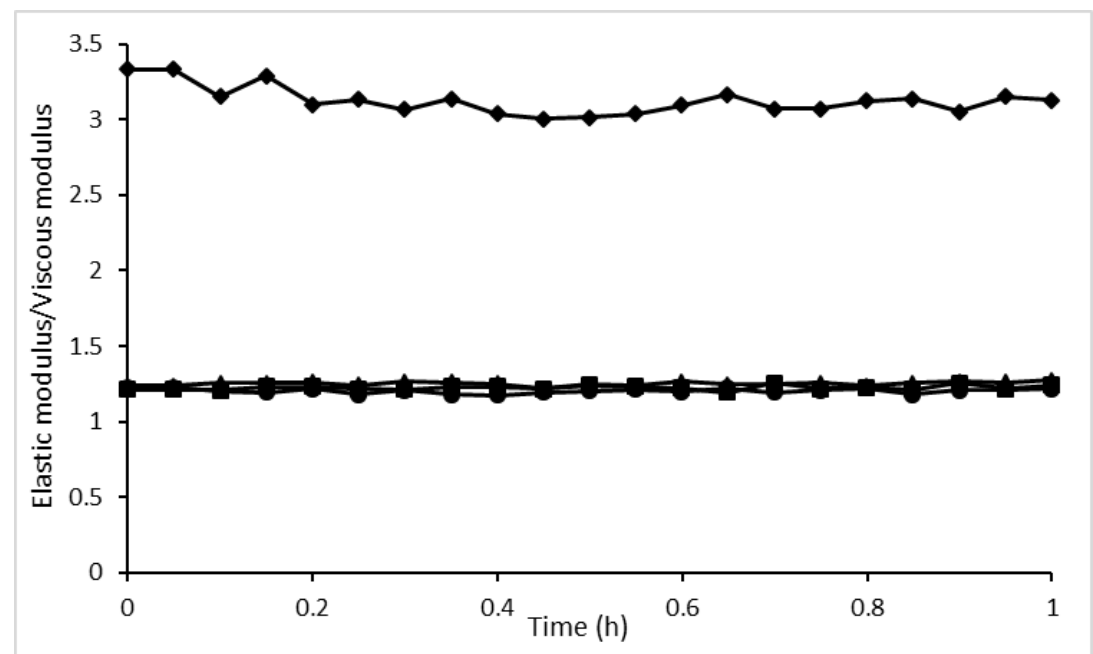

Figure 8. Elastic modulus in function of viscous modulus: (a) crude oil P1 diluted with 24\% (v/v) Heptol (3:7); and this solution containing: $(\bullet)$ FP31R1; $(\Delta)$ AF2; and $(\bullet)$ AF1 at shear rate de $10 \%$, frequency of $1 \mathrm{~Hz}$ and temperature of $25^{\circ} \mathrm{C}$.

In this case, in the presence of the mixture containing the larger quantity of toluene (Heptol 3:7), asphaltene aggregates were more solvated and more dispersed in the crude oil, able to alter both the values of $G^{\prime}$ and $G^{\prime \prime}$. This can hamper the formation of a film composed by the asphaltenes at the crude oil/air interface. This behavior is indicated by the reduced strength of the interfacial film formed in the system consisting of crude oil 1 $\left(19^{\circ} \mathrm{API}\right)$ containing this mixture of solvents compared to the system diluted with $33 \%$ Heptol (7:3).
In the presence of the antifoam additives AF1 and AF2, the strength of the interfacial film was similar to that in the system without addition of the products (crude oil containing Heptol 3:7), showing that these additives did not influence the strength of the superficial film.

Diversely, in the crude oil containing the formulation FP31R1, there was a significant increase in the elasticity of the interfacial film, showing that this additive migrated better to the crude oil/air interface if compared to the other systems tested. Furthermore, the presence of this 


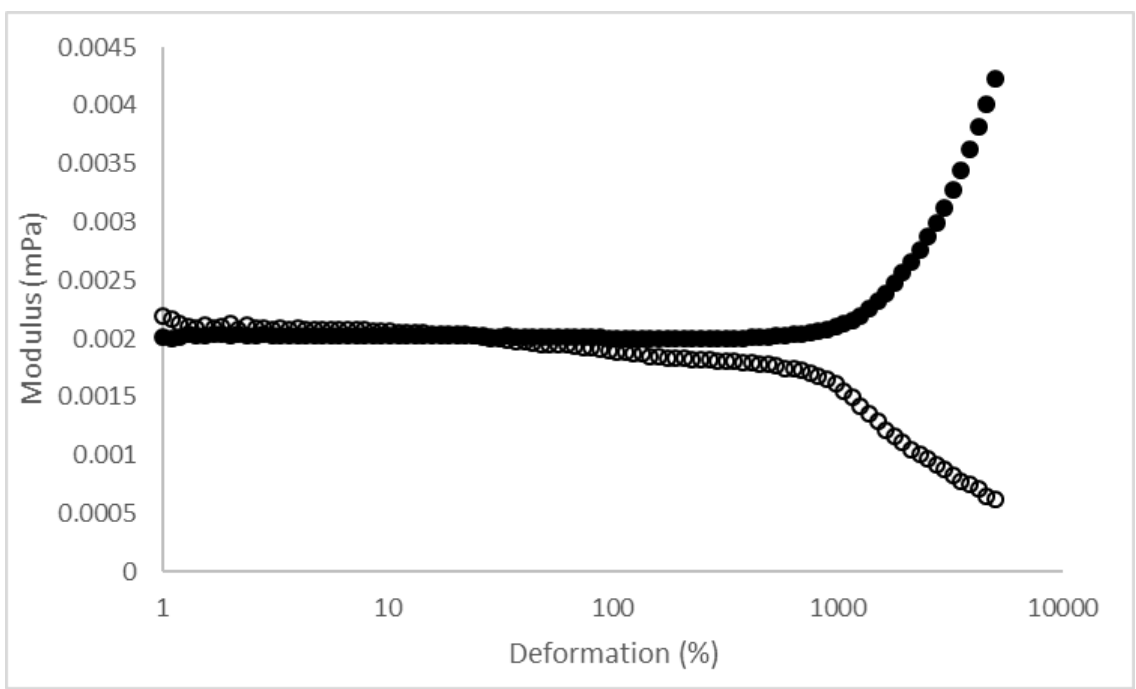

Figure 9. Values of $\mathrm{G}^{\prime}(\mathrm{O})$ and $\mathrm{G}^{\prime \prime}(\bullet)$ in function of the variation of deformation for crude oil P1 (19 $\left.{ }^{\circ} \mathrm{API}\right)$, aged for 17 hours at frequency of $1 \mathrm{~Hz}$ and temperature of $60^{\circ} \mathrm{C}$.

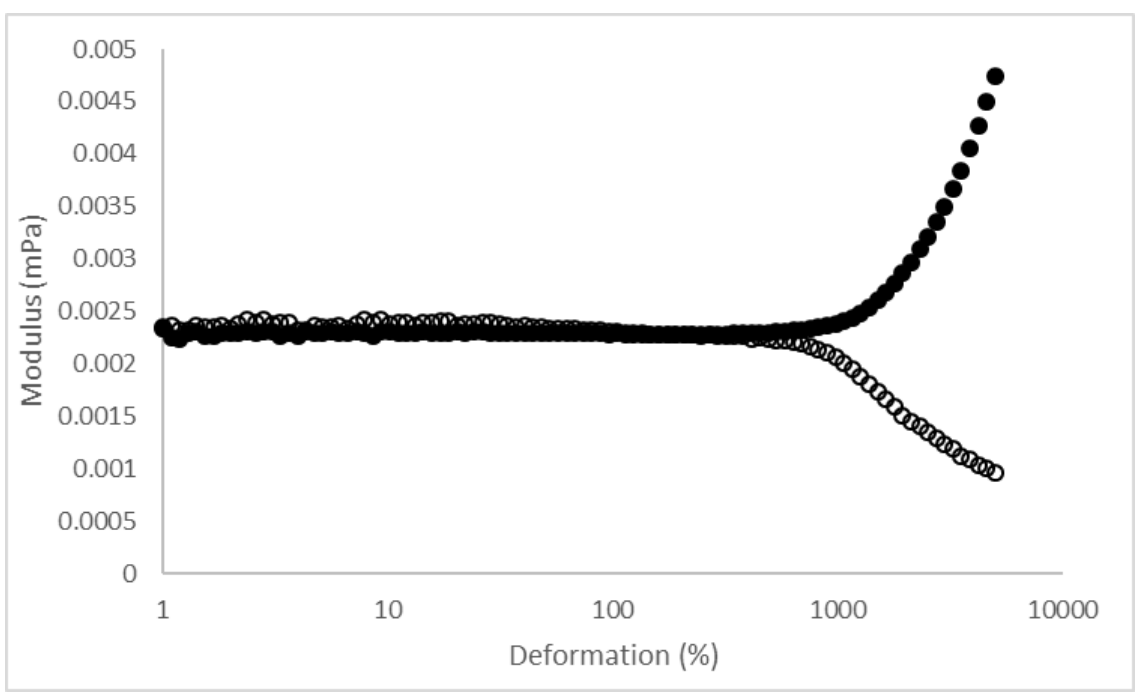

Figure 10. Values of $\mathrm{G}^{\prime}(\mathrm{O})$ and $\mathrm{G}^{\prime \prime}(\bullet)$ in function of the variation of deformation for crude oil P2 $\left(26^{\circ} \mathrm{API}\right)$, aged for 17 hours at frequency of $1 \mathrm{~Hz}$ and temperature of $30^{\circ} \mathrm{C}$.

additive increased the elasticity of the interfacial film, possibly because Pluronic 31R1 is a nonionic surfactant.

-Results obtained with the samples of pure crude oil P1 and P2

During preliminary tests, to adjust the interfacial rheology technique, we observed the occurrence of a temperature gradient from the base of the glass cuvette to the surface of the liquid, where the BiCone accessory was positioned. Because of this, it was necessary to perform tests at a higher temperature, so that the interface being analyzed would reach the desired temperature $(60$
${ }^{\circ} \mathrm{C}$ for crude oil P1 and $30{ }^{\circ} \mathrm{C}$ for the tests conducted with sample P2).

Oscillatory tests also were performed with a deformation variation of 1 to $5000 \%$, and fixed frequency of $1 \mathrm{~Hz}$, with the objective of observing the maximum deformation applied until rupture of the interfacial film (Figures 9 and 10, respectively, for P1 and P2). In both cases, the elastic modulus was greater than the viscous modulus, although with low significance, at low deformation levels, indicating the formation of an elastic film, and its rupture occurred at a deformation of around $20 \%$ for P1 (Figure 9) and 200\% for P2 (Figure 10). 


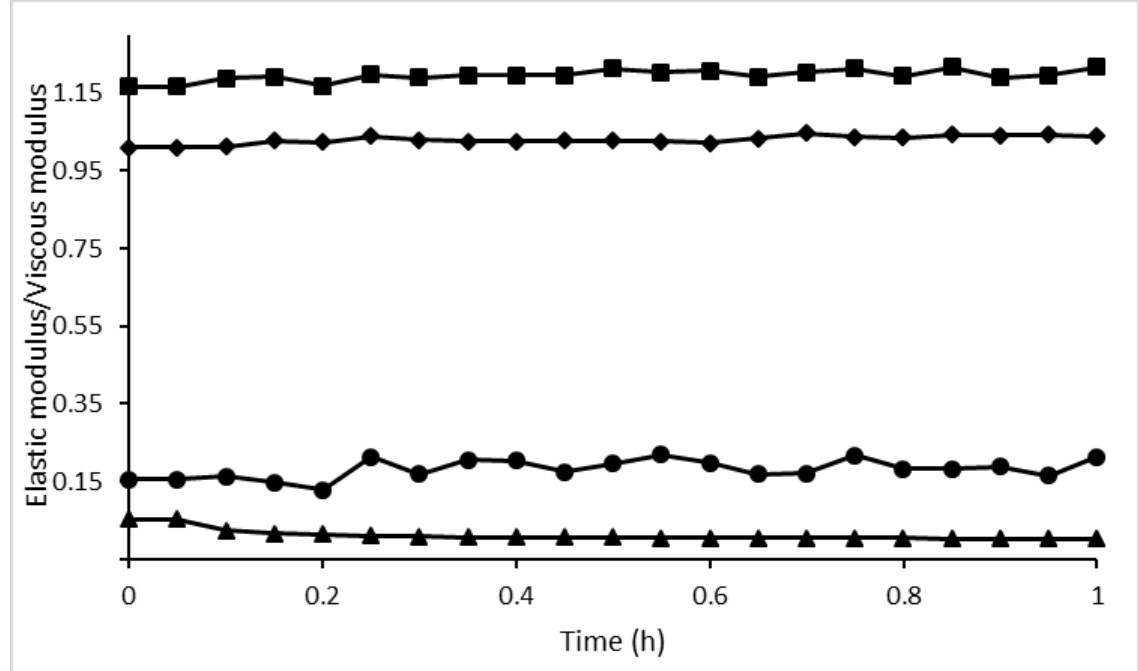

Figure 11. Elastic modulus in function of viscous modulus: $(\boldsymbol{\square})$ pure crude oil P1; and containing: $(\diamond)$ FP31R1; ( $\mathbf{\Delta})$ AF2; $(\bullet)$ AF1 at shear rate of $10 \%$, frequency of $1 \mathrm{~Hz}$ and temperature of $60{ }^{\circ} \mathrm{C}$.

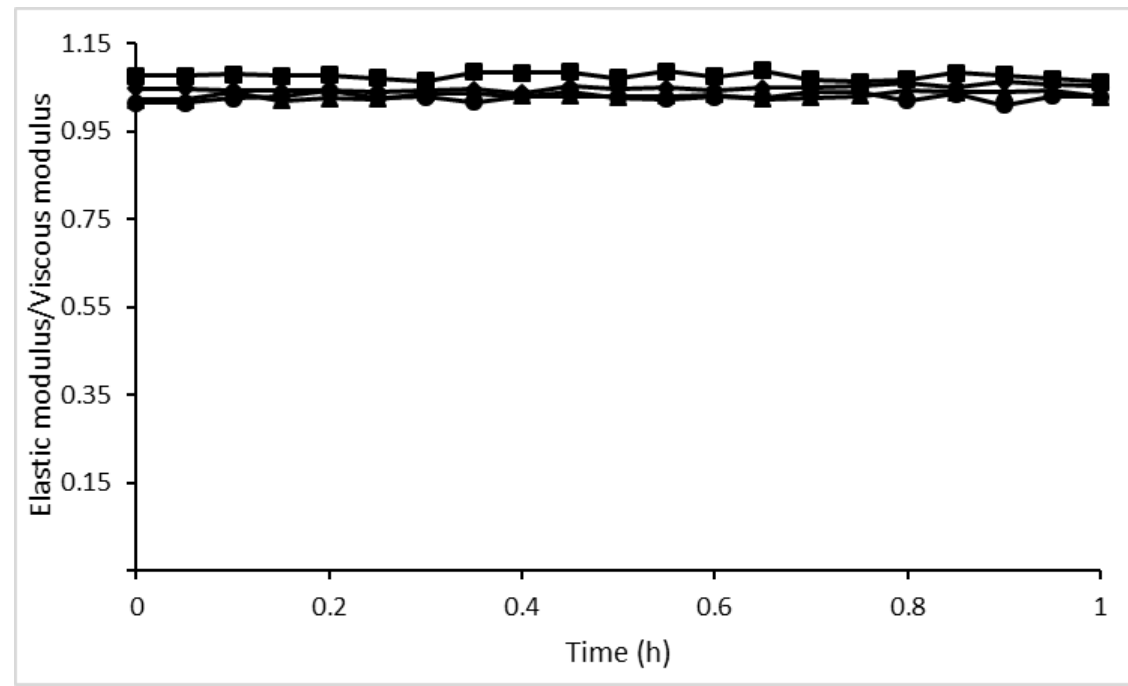

Figure 12. Elastic modulus in function of viscous modulus: (a) pure crude oil P2; and containing: ( $\downarrow)$ FP31R1; ( $\mathbf{\Delta})$ AF2; $(\bullet)$ AF1 at shear rate of $10 \%$, frequency of $1 \mathrm{~Hz}$ and temperature of $30^{\circ} \mathrm{C}$.

These results showed that the interfacial film formed with crude oil P2 was more resistant than that of P1, even though elastic and viscous modulus values were very similar for these samples. This behavior might have been caused by the higher viscosity of $\mathrm{P} 2$ at the testing temperature $\left(70 \mathrm{cP}\right.$, at $\left.30^{\circ} \mathrm{C}\right)$ than $\mathrm{P} 1(40 \mathrm{cP}$, at $\left.60{ }^{\circ} \mathrm{C}\right)$.

Finally, we performed oscillatory shear tests with variation of time but constant shear rate of $10 \%$ and frequency of $1 \mathrm{~Hz}$. In these tests, we monitored the behavior of the elastic modulus ( $\left.G^{\prime}\right)$ and viscous modulus $\left(G^{\prime \prime}\right)$ in function of the variation of time in interfacial films formed in crude oil P1 $\left(19{ }^{\circ} \mathrm{API}\right)$ at a temperature of $60{ }^{\circ} \mathrm{C}$ (Figure $11)$ and crude oil P2 $\left(26^{\circ} \mathrm{API}\right)$ at temperature of 30 ${ }^{\circ} \mathrm{C}$ (Figure 12).

As before, these tests were carried out in the presence of the commercial antifoaming agents AF1 and AF2, both at concentration of $20 \mathrm{ppm}$, and formulation FP31R1 at concentration of $100 \mathrm{ppm}$. The graphs also show the ratio of elastic modulus to viscous modulus in function of testing time to evaluate the film formed at the crude oil/air interface.

The results shown in Figure 11 indicate there was a reduction of the $G^{\prime} / G^{\prime \prime}$ ratio of the interfacial 
film formed by sample P1 with addition of $20 \mathrm{ppm}$ of the two commercial antifoaming agents in relation to the pure crude oil. A suggested explanation for this behavior is the greater impediment imposed by the commercial additives regarding migration and aggregation of asphaltenes at this interface, causing a reduction in the elasticity of the interfacial film in comparison with the pure crude oil with $19^{\circ} \mathrm{API}$. This interfacial rheology result corroborates the results of the foam formation efficiency tests (Figure 1a), where it was possible to observe that the height of the foam formed by that crude oil sample with the addition of AF1 and AF2 was considerably lower than that of the pure crude oil.

However, for crude oil P1 containing FP31R1, the interfacial film was similar to that of the pure crude oil, showing that this formulation did not contribute to destabilize this film; a result also in line with the data obtained for foaming test (Figure 1b), where the crude oil mixed with that formulation produced foam with similar height as the pure crude oil.

In Figure 12 one can observe that $G^{\prime} / G^{\prime \prime}$ ratios for the pure crude oil P2 and its mixture with additives were very close to each other. This behavior might be due to the greater resistance of the interfacial film formed with this oil sample.

In the case of the interfacial film observed in crude oil P2 in the presence of the formulation FP31R1, results indicate that the foam is more stable than that observed in the presence of the two commercial antifoaming agents. Results of the antifoaming efficiency test show that the interfacial film is more fragile, generating an unstable foam, as also observed in the foam formation test (Figure 1b).

The results obtained with sample P2 supported the results obtained previously with crude oil P1 (Figure 11).

\section{CONCLUSIONS}

The present study shows that rheology measurements of the crude oil/air interface utilizing the BiCone accessory can be correlated with foam formation tests of crude oil samples.
When diluting crude oil, the presence of a larger quantity of flocculant solvent, heptane, promoted greater resistance of the interfacial film. This behavior can be attributed to the larger quantities or levels of asphaltene aggregates present at the crude oil/air interface. Nevertheless, the dilution with a larger quantity of solvent toluene promoted dispersion of the asphaltenes in the crude oil, hindering the formation of aggregates.

The evaluation of the antifoaming agents used in this work by means of rheology tests of the crude oil/air interface without the dilution of the oil sample presented good results. These test results corroborated those obtained from the tests of foam formation, and the additives that were more efficient in reducing foaming were those containing higher concentrations of silicone.

\section{ACKNOWLEDGMENTS}

This work was supported by Conselho Nacional de Desenvolvimento Científico e Tecnológico (CNPQ), by Coordenação de Aperfeiçoamento de Pessoal de Nível Superior (CAPES)-Finance Code 001, by Fundação Carlos Chagas Filho de Amparo à Pesquisa do Estado do Rio de Janeiro (FAPERJ), and by PETROBRAS.

\section{REFERENCES}

Adil, I.; Maini, B.B. Role of asphaltenes in foamy oil flow. Journal of Canadian Petroleum Technology, v. 46(4), p. 18-23, 2007. https://doi.org/10.2118/07-04-01

Álvarez, L.; Díaz, M. E.; Montes, F. J.; Galán, M. A. Langmuir technique and Brewster angle microscope studies of the interfacial behavior of bitumen, asphaltenes and maltenes at the airwater interface. I. Effect of different spreading solution volumes. Fuel, v. 89, p. 691-702, 2010. https://doi.org/10.1016/i.fuel.2009.08.036

Blázquez, C.; Dalmazzone, C.; Emond, E., Schneider, S. Crude oil foams: Testing and ranking of antifoams with the depressurization test. Energy \& Fuels, v. 31, p. 1285-1294, 2017. https://doi.org/10.1021/acs.energyfuels.6b02567 
Blázquez, C.; Dalmazzone, C.; Emond, E., Schneider, S. Crude oil foams. Part 1 - A novel methodology for studying non-aqueous foams formed by depressurization. Fuel, v. 171, p. 224237, 2016.

https://doi.org/10.1016/j.fuel.2015.11.092

Blázquez, C.; Emond, E.; Schneider, S.; Dalmazzone, C.; Bergeron, V. Non-aqueous and crude oil foams. Oil \& Gas Science and Technology, v. 69 (3), p. 467-479, 2014.

https://doi.org/10.2516/ogst/2013186

Ekott, E. J.; Akpabio, E. J. A review of water-incrude oil emulsion stability, destabilization and interfacial rheology. Journal of Engineering and Applied Sciences, v. 5(6), p. 447-452, 2010. https://doi.org/10.3923/jeasci.2010.447.452

Fan, Y.; Simon, S.; Sjöblom, J. Influence of nonionic surfactants on the surface and interfacial film properties of asphaltenes investigated by Langmuir balance and Brewster angle microscopy. Langmuir, v. 26, p. 10497-10505, 2010.

https://doi.org/10.1021/la100258h

Førdedal, H.; Schildberg, Y.; Sjöblom, J.; Volle, JL. Crude oil emulsions in high electric fields as studied by dielectric spectroscopy. Influence of interaction between commercial and indigenous surfactants. Colloids and Surfaces A: Physicochemical and Engineering Aspects, v. 106, p. 33-47, 1996. https://doi.org/10.1016/09277757(95)03354-8

Fraga, A. K.; Rezende, D. A.; Santos, R. F.; Mansur, C. R. E. Method to evaluate foaming in petroleum. Brazilian Journal of Petroleum and Gas, v. 5(1), p. 25-33, 2011.

https://doi.org/10.5419/bipg2011-0004

George, D. S.; Hayat, O.; Kovscek, A. R. A microvisual study of solution-gas-drive mechanisms in viscous oils. Journal of Petroleum Science and Engineering, v. 46, p. 101-119, 2005.

https://doi.org/10.1016/i.petrol.2004.08.003

Heyer, P.; Läuger, J. Interfacial shear rheology of films formed by coffee. Annual Transactions of the Nordic Rheology Society, v. 16, 2008.

Höhler, R.; Cohen-Addad, S. Rheology of liquid foam. Journal of Physics: Condensed Matter, v. 17, p. 1041-1069, 2005. https://doi.org/10.1088/0953$8984 / 17 / 41 / R 01$
Honse, S. O.; Ferreira, S. R.; Mansur, C. R. E.; Lucas, E. F.; González, G. Separation and characterization of asphaltenic subfractions. Química Nova, v. 35, p. 1991-1994, 2012. https://doi.org/10.1590/\$0100-40422012001000019

Kallevik, H., Hansen, S. B., Saether, O., Kvalheim, O. M., Sjöblom, J. J. Disper. Crude oil model emulsion characterized by means of near infrared spectroscopy and multivariate techniques. Journal of Dispersion Science and Technology, v. 21, p. 245-262, 2000.

https://doi.org/10.1080/01932690008913265

Khoshandam, A.; Alamdari, A. Kinetics of asphaltene precipitation in a heptane-toluene mixture. Energy \& Fuels, v. 24, p. 1917-1924, 2010. https://doi.org/10.1021/ef9012328

Kilpatrick, P. K.; Spiecker, P. M. Asphaltenes emulsions. Encyclopedic Handbook of Emulsion technology. New York: Marcel Dekker, p. 707, 2001. https://doi.org/10.1201/9781420029581.ch30

Koehler, S. A., Foam Drainage. Foam Engineering: Fundamentals and Applications. John Wiley and Sons, pp. 28, 2012.

https://doi.org/10.1002/9781119954620.ch3

Krägel, J.; Derkatch, S. Interfacial shear rheology. Current Opinion in Colloid \& Interface Science, v. 15, p. 246-255, 2010. https://doi.org/10.1016/i.cocis.2010.02.001

Langevin, D. Influence of interfacial rheology on foam and emulsion properties. Advances in Colloid and Interface Science, v. 88, p. 209-222, 2000. https://doi.org/10.1016/S0001-8686(00)00045-2

Lobato, M. D.; Pedrosa, J. M.; Lago, S. Effects of block copolymer demulsifiers on Langmuir films of heavy and light crude oil asphaltenes. Energy \& Fuels, v. 28, p. 745-753, 2014.

https://doi.org/10.1021/ef402055v

Lobato, M. D.; Pedrosa, J. M.; Möbius, D.; Lago, S. Optical characterization of asphaltenes at the air-water interface. Langmuir, v. 25, p. 1377-1384, 2009. https://doi.org/10.1021/la803431k

Mohammed, R. A.; Bailey, A. I.; Luckham, P. F.; Taylor, S. E. Dewatering of crude oil emulsions 1. Rheological behaviour of the crude oil-water interface. Colloids and Surfaces A: Physicochemical and Engineering Aspects, v. 80, p. 223-235, 1993. https://doi.org/10.1016/09277757(93)80202-P 
Oliveira, P. F., Santos, I. C. V. M., Vieira, H. V. P., Fraga, A. K., Mansur, C. R. E. Interfacial rheology of asphaltene emulsions in the presence of nanoemulsions based on a polyoxide surfactant and asphaltene dispersant. Fuel, v. 193, p. 220229, 2017. https://doi.org/10.1016/i.fuel.2016.12.051

Phukan, M.; Koczo, K.; Falk, B.; Palumbo, A. New silicon copolymers for efficient demulsification. Society of Petroleum Engineers, SPE 128553, 2010. https://doi.org/10.2118/128553-MS

Poindexter, M. K.; Zaki, N. N.; Kilpatrick, P. K.; Marsh, S. C.; Emmons, D. H. Factors contributing to petroleum foaming. 1. Crude oil systems. Energy and Fuels, v. 16, p. 700-710, 2002.

https://doi.org/10.1021/ef010224i

Rezende, D. A. Bittencourt, R. R., Mansur, C. R. E. Evaluation of the efficiency of polyether-based antifoams for crude oil. Journal of Petroleum Science and Engineering, v. 76, p. 172-177, 2011. https://doi.org/10.1016/j.petrol.2011.01.009

Rocker, J.; Mahmoudkhani, A.; Bava, L.; Wilson, R. Low environmental impact non-silicone defoamers for use in oil/gas separators. SPE Eastern Regional Meeting. Conference paper; Columbus, OH; United States; p. 429-441, 2011. https://doi.org/10.2118/149462-MS

Sheng, J. J.; Maini, B. B.; Hayes, R. E.; Tortike W. S. Experimental study of foamy oil stability. Journal of Canadian Petroleum Technology, v. 36 (4), p. 31-37, 1997. https://doi.org/10.2118/97-04-02

Sheng, J. J.; Maini, B. B.; Hayes, R. E.; Tortike, W.S. A non-equilibrium model to calculate foamy oil properties. Journal of Canadian Petroleum Technology, v. 38(4), p. 38-45, 1999. https://doi.org/10.2118/99-04-04
Spiecker, P. M., Kilpatrick, P. K. Interfacial rheology of petroleum asphaltenes at the oil-water interface. Langmuir, v. 20, p. 4022-4032, 2004. https://doi.org/10.1021/la0356351

Szklo, A. S. Fundamentos do Refino do Petróleo. Rio de Janeiro: Editora Interciência, 2005. In Portuguese)

Tadros, T. Application of rheology for assessment and prediction of the long-term physical stability of emulsions. Advances in Colloid and Interface Science, v. 108-109, p. 227-258, 2004. https://doi.org/10.1016/i.cis.2003.10.025

Wang, J.; Yuan, Y.; Zhang, L.; Wang, R. The influence of viscosity on stability of foamy oil in the process of heavy oil solution gas drive. Journal of Petroleum Science and Engineering, v. 66, p. 6974, 2009. https://doi.org/10.1016/i.petrol.2009.01.007

Wylde, J. J. Successful field application of novel, nonsilicone antifoam chemistries for high-foaming heavy-oil storage tanks in Northern Alberta. SPE Production \& Operations, v. 25, p. 25-30, 2010. https://doi.org/10.2118/117176-PA

Zaki, N. N.; Poindexter, M. K.; Kilpatrick, P. K. Factors contributing to petroleum foaming. 2. Synthetic crude oil systems. Energy \& Fuels, v. 16, p. 711-717, 2002.

https://doi.org/10.1021/ef010225a 